\title{
Fransız Kaynaklarına Göre Osmanlı Devleti Topraklarında Kurulan Yabancı Sermayeli Bankalar Arasındaki Rekabet (1856-1914)
}

\section{Dr. Öğr. Üyesi Damla Ayoğlu Duman}

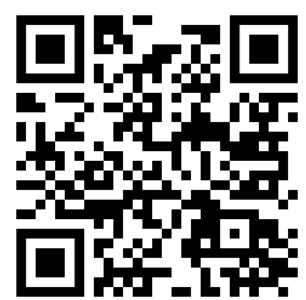

Geliş tarihi: 06.03.2020

Kabul tarihi: 14.07.2020

\section{Atıf bilgisi:}

IBAD Sosyal Bilimler Dergisi

Sayı: $8 \quad$ Sayfa: $425-437$

Yıl: 2020 Dönem: Güz

This article was checked by Turnitin. Similarity Index $05 \%$

Bu makalede araştırma ve yayın etiğine uyulmuștur.

${ }^{1}$ Akdeniz Üniversitesi, Türkiye, ayoglu@akdeniz.edu.tr

ORCID ID 0000-0003-0256-9025

* Sorumlu yazar
$\ddot{O Z Z}$

Bu çalıșmada, Osmanlı İmparatorluğu ile yakın ilișkileri olan Fransız Devletinin, 19. yüzyılın ikinci yarısından itibaren Osmanlı topraklarında kurulan yabancı sermayeli bankalar ve yabancı banka şubelerinin hakkında düşünceleri, Fransız Ekonomi ve Finans Bakanlığı arşivlerinden yararlanılarak ortaya konulacaktır. Osmanlı İmparatorluğunda banka kurma düşüncesi sanayileşmiş Avrupa devletlerine göre daha geç tarihlerde gerçekleşmiştir. Bir banka kurma fikrinden ilk defa 1856 'da ilan edilen Islahat Fermanında bahsedilmiştir. İlk olarak iki Galata bankeri tarafindan Bank-1 Dersaadet kurulmus ama bu bankanın ömrü çok uzun olmamıştır. Ancak Osmanlı topraklarında banka kurma işinin kârlı olduğunu gören yabanc1 devletler yeni teklifler getirmişlerdir. Bu teklifler sonucunda 1857 yılında İngiliz sermayesi ile Osmanlı bankası kurulmuş yedi yıl sonra Fransız sermayesi de bu bankaya ortak olmuştur. 1881 yılında Alman yatırımları artmaya başlayınca Deutsche Bank gibi Alman bankalarının kurduğu banka şubeleri, Osmanlı Bankasına rakip olmuşlardır. Dolayısıyla Osmanlı İmparatorluğunda açılan yabancı bankalar konusunda Almanya ve Fransa arasında önemli bir rekabet ortaya çıkmıştır.

Anahtar Kelimeler: Osmanlı İmparatorluğu, Yabancı Sermayeli Bankalar, Fransa, Almanya 
Competition between Foreign Capital Banks Established in the Soils of the Ottoman State According to the French Resources (1856-1914)

Assist. Prof. Dr. Damla Ayoğlu Duman

First received: 06.03 .2020 Accepted: 14.07 .2020

\section{Citation:}

IBAD Journal of Social Sciences

Issue: 8

Pages: 425-437

Year: 2020

Session: Fall

This article was checked by Turnitin. Similarity Index 05\%

${ }^{1}$ Akdeniz Üniversitesi, Türkiye, ayoglu@akdeniz.edu.tr

ORCID ID 0000-0003-0256-9025

* Corresponding Author

\begin{abstract}
The idea of establishing a bank in the Ottoman Empire occurred later than industrialized European states. The idea of establishing a bank was mentioned for the first time in the Islahat Edict, which was announced in 1856. First, Bank-1 Dersaadet was established by two Galata bankers, but the life span of this bank was not very long. However, foreign states, who thought that the establishment of a bank in the Ottoman lands was profitable, brought new proposals. As a result of these proposals, Ottoman Bank was established in 1857 with English capital, and French capital became a partner of this bank seven years later. When German investments started to increase in 1881, bank branches established by German banks such as Deutsche Bank became rivals to the Ottoman Bank. In this study, the competition between foreign banks and foreign bank branches in the early twentieth century will be revealed by using archives of the French Ministry of Economy and Finance.
\end{abstract}

Key Words: Ottoman Empire, Foreign Capital Banks, France, Germany 


\section{GİRIŞ}

17. yüzyıldan itibaren gelişmiş ülkelerde ilk modern bankalar kurulmaya başlamıştır. Özellikle 18. ve 19. yüzyılda, Sanayi Devriminin dünyada hızla yayılışıyla, bu devrimi gerçekleştiren ülkelerin gerek sömürge gerekse dış ticaret ile elde ettikleri geliri, sanayi sektörüne kredi olarak aktarması ile de bankalar artmaya ve gelişmeye başlamıştır. Bu dönemde özellikle İngiltere ve Fransa gibi sanayileşmiş ülkelerde bankacılık hızla gelişmiştir.

Osmanlı İmparatorluğu sanayileşen Batılı devletler karşısında ekonomik alanda oldukça geri kalmıştır. $\mathrm{Bu}$ dönemde Osmanlı topraklarında bankalardan bahsetmek de pek mümkün değildir. 17. yüzyıldan itibaren Osmanlı İmparatorluğu'nun merkezi gücü zayıflamaya başlayınca, devlet vergi toplama konusunda sıkıntılar yaşamaya başlamıştır. 17. ve 18. yüzyıla genel olarak bakılacak olursa Osmanlı devletinin vergi toplamak konusunda başarısız olduğu söylenebilir. Toplanan vergilerin önemli kısmı taşradaki ayanın ve diğer yerel güçlerin elinde kalmıştır. Bu dönemde Anadolu'da toplanan vergilerin sadece \% 3'lük bölümü devlet kasasına ulaşmıştır. Devlet gelirlerinin kısıtlı kalması ise ciddi mali problemlerin yaşanmasına sebep olmuştur.

Osmanlı Devleti'nin mali sorunlarının tek sebebi vergi gelirlerinin devlet kasasına ulaşmaması değil, giderlerin fazlalığı da olmuştur. Özellikle savaşlar devletin harcamalarını çok arttırmıştır. 1683 y1lındaki Viyana yenilgisi ve sonrasındaki diğer yenilgiler Osmanlı ekonomisini oldukça olumsuz etkilemiştir (Tabakoğlu, 2009, s. 317).

Devletin ekonomisi 18. yüzyılın ikinci yarısı ve 19. yüzyıl boyunca toparlanamamıştır. Devam eden savaşlar mali sorunları arttırmış para düzenini bozmuştur. Bu dönemlerde paralar tağşişe ${ }^{1}$ uğramış bu da enflasyonu arttırmıştır. Fiyatların artması özellikle maaşını parayla alan devlet memurlarını olumsuz etkilemiştir. Kuruşun gümüş içeriği I. Abdülhamit (1774-1789) döneminde \% 15 kadar azalmıştır.1775'te devlet mali sorunları karşısında esham adıyla bir iç borçlanma başlatmıştır. Eshamın kișiler arasında tedavülünün serbest bırakılması kâğıt paranın habercisi olmuștu. 1768'lerden 1840'lara kadar yaşanan savaşlar, yapılan reformlar Osmanlı maliyesini olumsuz etkilemiş paranın değeri düşmeye devam etmiştir (Tabakoğlu, 2009, s. 322-323).

19. yüzyılda ise durum değişmiştir. Yeniden güç kazanmaya başlayan merkezi devlet vergi gelirlerini ayanın elinden almaya başlamıştır. Merkeze ulaşan gelirler sürekli artmıştır. Ancak bu artış devletin mali sorunlarını sona erdirememiştir. Tağşişler, dış borçlar derken devletin mali açıdan sorunları artmıştır. Özellikle para düzeninin bozulması yabancı tüccarları ve dolayısıyla yabancı devletleri rahatsız etmiştir. Bu nedenle Osmanlı Devleti'ne bir banka kurulması konusunda baskılar artmıştır (Pamuk, 2014, s. 111-115).

Devletin geliri toplama konusunda yaşadığı sorunlar ve savaşlar sebebiyle artan giderleri sonucunda, 19. yüzyılın ikinci yarısında kurulmaya başlayan yabancı sermayeli bankalara ve yabancı banka şubelerine gelene kadar, Osmanlı Devleti ciddi mali sorunlarla karşı karşıya kalmıştır.

Tağşişler, iç borçlanma Osmanlı mali sorunlarını çözemeyince 1854 Kırım Savaşı sırasında Avrupa piyasalarına tahvil satarak dış borç almaya başlamıştır. 1850'lerden sonra tağşiş uygulamaları da sona ermiştir. Bütçe açıklarının finansmanı için dış borç alınıyorken devlet bir süre sonra bu borçları ödemekte zorluk çekmiştir. 1876 yılında ise dış borçların ödemelerini durdurmak zorunda kalmıştır. Daha sonra, 1877-1878 yıllarında bir başka savaş Osmanlı- Rus Savaşı nedeniyle nüfustaki gerileme ve toprak kayıpları sonucunda Osmanlı maliyesi yine yara almıştır. Osmanlı- Rus Savaşı bütçe açıklarını arttırmış, bütçe gelirlerinin giderleri karşılama oranı \% 43,4'e inmiştir (Güran, 2014, s. 321 325). Bu dönemlerde toprak kayıplarındaki artış mali sorunlarında çoğalmasına sebep olmuştur. $\mathrm{Bu}$ şartlar altında yeni borç almakta mümkün olmamış ve 1881 yılında Duyun-u Umumiye kurulmuştur.

\footnotetext{
1 Tağşişler para birimindeki gümüş içeriğinin devlet tarafindan azaltılmasıdır. Devletin tağşiş yapmasındaki en önemli sebep, kısa vadeli ek mali gelir elde etmektir. Ancak tağşişler yarattıkları fiyat artışları sonucunda, uzun vadeli mali sorunlar ve ciddi bir siyasal muhalefet yaratmışlardır. 1585-86 tağşişine kadar Osmanlının para düzeninde akçenin değeri fazla değişmemiştir. En önemli tağşiş Tazminat Döneminden hemen önce, iç ve dış bunalımlarla dolu Padişah II. Mahmut'un saltanatı (1808-1839) sırasında yapılmışıtır (Aysan, 2018, s. 102-105).
} 
Osmanlı Devleti gelir kaynaklarının bir kısmını Avrupa devletlerine bırakmıştır (Pamuk, 2017, s. 109115).

Osmanlı Devleti'nin mali sorunlarını çözümlemek için giriştiği tağşişler iç ve dış borçlanma sorunu çözemeyince ve para düzeninin iyice bozulması sebebiyle yabancı tüccarlar rahatsız olunca bir banka kurulması konusunda baskılar artmıştır. $\mathrm{Bu}$ dönemde para birimindeki dalgalanmalar ve farklı bölgelerde farklı kurların uygulanması da yabancı tüccarlar için sorun yaratmıştır.

$\mathrm{Bu}$ sorunlar sonucunda Avrupa devletlerinden bir banka kurulmasıly ilgili talepler gelmeye başlamıştır. Şevket Pamuk'a göre bu isteğin sebebi ticaretin genişlemesi ve tüccarların kredi ihtiyaçlarının artmasıdır. Aynı zamanda yabancı bankalar Osmanlı Devleti'nin mali sorunlarını gidermek için borç da veriyorlardı. (Pamuk, 2014, s. 115-117). Bu ihtiyaç doğrultusunda, 18 Şubat 1856 'da ilan edilen Islahat Fermanı'nda ilk defa banka kurulmasından bahsedilmiștir. Osmanlı Devletinde, Tanzimat Dönemine kadar bankalara rastlanmamaktaydı. 19. yüzyılın başlarında yapılan serbest ticaret anlaşmaları sonucunda devletin gümrükler üzerindeki kontrolünün ortadan kalkması, ticaret hacminin de artışıyla birlikte dış ticaret açığı çoğalmıştır. Bunun sonucunda Osmanlı pazarı sanayileşmiş Avrupalı devletler için bir açık pazar haline gelmiş ve bozulan para düzenini düzeltmek için modern bir bankaya ihtiyaç duyulmuştur ve 19. yüzyılın ikinci yarısından itibaren yabancı sermayedarlar Osmanlı topraklarında bankalar kurmaya başlamışlardır.

19. yüzyılın ikinci yarısında imparatorluk topraklarında, İngiliz sermayesi ile kurulan ilk yabancı sermayeli banka Osmanlı Bankası olmuştur. 1863 yılında kurulan İngiliz sermayeli Osmanlı Bankası'na \% 50 payla katılan Fransız sermayesi ile Osmanlı Bankasının ismi Bank-1 Osman-i Şahane olarak değişmiştir. Bu banka devlete kısa vadeli borçlar vermiş, devletin dış borçlarının ödenmesinde imtiyazlar sağlamıştır. Hem bu banka, hem de akabinde kurulan diğer yabancı sermayeli bankaların ana faaliyet alanı Osmanlı Hazinesine iç ve dıș borç sağlamak olmuştur. Nitekim bu bankaların temel ișlevi Osmanlı Devleti'nin ekonomik kalkınmasına fayda sağlamaktan ziyade, ülkenin bu borç trafiğinden ve döviz işlemlerinden yüksek spekülatif kazançlar sağlamak olmuştur. Aynı zamanda İmparatorlukta yatırım yapan yabancı sermayeli kuruluşları finansal açıdan desteklemişlerdir. (Türkiye Bankalar Birliği, 2008, s.2). Yabancı sermayedarların banka kurmak ya da banka şubesi açmak için Osmanlı topraklarına ilgi duymalarının çeşitli nedenleri olmuştur. Bunlardan ilki özellikle 1899 sonrasında uluslararası ticaretin fazlalaşması ve yabancı sermayedarların Osmanlıyla yapılan ticareti kolaylaştırmak için modern bankalar kurmak istemesiydi. Bir diğer sebep ise Avrupa'daki büyük güçlerin Osmanlı Devletini ekonomik ve siyasi olarak etkileri altında tutabilmek için giriştikleri rekabetti. Aynı zamanda Osmanlı İmparatorluğunun mali sorunları arttıkça Osmanlı İmparatorluğu da yabancı finansmanın topraklarına girmesini desteklemiştir (Hanedar, 2015, s. 210-212).

$\mathrm{Bu}$ çalışmanın amacı, Osmanlı devletinin mali sorunlarının arttığı dönemde yabancı sermaye ile kurulan banka ve yabancı banka şubeleri arasındaki rekabeti ortaya koymaktır. Bu rekabetin, Osmanlı topraklarında yapılan yabancı yatırımlarda önemli bir yere sahip olan Fransızların, büyükelçilik ve konsolosluklardan gönderilen belgelere nasıl yansıdığını ortaya koymaktır. Özellikle İngiliz ve Alman sermayedarların kurdukları banka ve banka şubelerinin Fransız Devleti tarafindan nasıl karşılandığından bahsedilecektir.

Aynı zamanda farklı ülkelerin sermayedarlarının kurduğu bankalar ve yabancı banka şubeleri hakkında Fransız Devletinin kendi bankalarını korumak üzere nasıl bir tavır aldığı, Fransız Ekonomi ve Finans Bakanlığı arşivlerinden yararlanılarak ortaya koyulacaktır. Bu çalışmanın literatüre katkısı, Fransız arşiv belgelerinden yararlanılarak, kurulan yabancı bankaların arasındaki rekabetin ortaya konulmasıdır. Makalenin ilk bölümde 19. yüzyılın sonlarından itibaren Osmanlı topraklarında kurulan yabancı sermayeli bankalar ve açılan yabancı banka şubelerinden bahsedilecektir. İkinci bölümde, Fransız ve Alman bankaları arasındaki ve Alman bankalarının kendi aralarındaki rekabetten bahsedilecektir. Son bölümde ise Fransızların, Osmanlı Banka'sıyla rekabet edeceğini düşündükleri İngiliz sermayeli Türkiye Milli Bankasından söz edilecektir. 


\section{OSMANLI TOPRAKLARINDA KURULAN YABANCI SERMAYELİ BANKALAR}

Osmanlı İmparatorluğunun çeşitli mali sorunlar yaşadığı dönemde banka kurma teklifi ilk defa Islahat Fermanından önce 1836 yılında, İngilizlerden gelmiştir. Bu dönemde hem yabancılardan hem de yerli sermayedarlardan banka kurma teklifleri gelmiştir. Bu rekabet sonucunda bir banka kurulması biraz zaman almış ve 1847 yılında, iki Galata bankeri kaimelerin değerinin sabit tutulması için devletin de desteği ile İstanbul bankası diğer adıyla Bank-1 Dersaadet'i kurmuştur. Ancak bu banka çok uzun ömürlü olmamış ve spekülasyonlar, ödeme güçlükleri sonucunda 1852 y1lında iflas etmiştir (Apak ve Tay, 2012, s. 66-67). Ayrıca Dersaadet Bankası yaptığı işlemler ile devletin ithalatının artmasına sebep olmuştur. Bu durum sebebiyle Dersaadet Bankası deneyimi, belki dünyada ilk kez, bankaların tasarrufu değil, tüketimi artırmada büyük rol oynayabileceğini göstermiştir (Kazgan, 1997, s. 28).

Tablo 1'de Dersaadet Bankası ve sonrasında açılan yabancı sermayeli bankalar ve kuruluş yılları gözükmektedir. Dersaadet Bankası deneyimden sonra yabancı yatırımcılar banka kurmak konusunda teklifler sunmaya devam etmişlerdir. Bunun önemli sebebini imparatorluğun borçlanma ihtiyacı ve yüksek faizler oluşturmuştur (Karta, 2014, s. 158). Bu talepler sonucunda kurulan ilk yabanc1 sermayeli banka 1856 y1lında İngiliz sermayeli Osmanlı Bankası olmuştur. 7 yıl sonra, 1863 yılında bir Fransız grubu \%50 sermaye payı ile Osmanlı Bankasına katılmış ve bankanın ismi Bank-ı Osmanii Şahane olmuştur. Osmanlı İmparatorluğunda farklı Fransız bankaları olsa da, bu topraklarda Fransız etkisi açısından en önemli yere sahip olan banka Bank-1 Osmani-i Şahanedir. Bu banka bir yandan ticari işlemler yaparken bir yandan da devlete borç sağlamıştır (Ayoglu Duman, 2016, s. 48). Aynı zamanda banka Galata bankerlerine göre daha uygun faizlerle borç vermiş ancak yabancı bankalar artıkça önemi azalmıştır.19. yüzyılın üçüncü çeyreğinde İstanbul'da devlete borç vermek için yeni yabancı sermayeli bankalar ve yabancı banka şubeleri kurulmuştur.

Tablo 1. Osmanlı Devleti’nde Kurulan Başlıca Yabancı Bankalar

\begin{tabular}{|l|l|}
\hline Banka & Kuruluş y1lı \\
\hline İstanbul Bankas1 (Dersaadet Bankas1) & 1847 \\
\hline Osmanlı Bankas1 & 1856 \\
\hline Türkiye Bankas1 & 1860 \\
\hline Bank-1 Osmani-i Şahane & 1863 \\
\hline La Societe General & 1864 \\
\hline The Ottoman Financial Association & 1866 \\
\hline Credit General Ottoman & 1869 \\
\hline Austro-Ottoman Bank & 1872 \\
\hline Austro-Turkish Bank & 1872 \\
\hline La Societe Ottoman de Change et de Valeurs & 1872 \\
\hline Selanik Bankas1 & 1888 \\
\hline
\end{tabular}

Kaynak: İstanbul Menkul Kıymetler Borsası, Osmanlı'dan Günümüze Türk Finans Tarihi, 1, 280.

1863 yılında İstanbul'da, İngiliz ve Fransız ortaklığında kurulan Bank-1 Osmani-i Şahane ve 1875 yılında burada şube açan Fransız bankası Credit Lyonnais faaliyet göstermeye başlamıştır. Hemen sonrasındaysa önemli bir ticaret şehri olan İzmir'de Credit Lyonnais şube açmıştır. Bunu, üç yıl sonra yine İzmir'de şube açan Midilli (Mitylene) Bankası izlemiştir (Frangakis-Syrett, 2009, s. 118-119). Şubat 1875 yılında, Credit Lyonnais İstanbul'da parlak bir başlangıç yapmış olmasına rağmen, bankanın İstanbul şubesi 1880 yılına kadar zararda çalışmıştır (Thobie, 1977, s. 112-113).

1881'den itibaren Avrupa'daki bankaların Osmanlı topraklarında açtıkları şube sayısı artmaya başlamıştır. Bu dönemde açılan yabancı banka şubeleri, Avrupa'daki sanayileşmiş devletlerin etki alanı olarak seçtikleri bölgelerde yoğunlaşmışlardır. Sanayileşmiş Avrupalı devletler bu bölgelerde özellikle kendi firmalarını desteklemişler ve kendi ülke çıkarlarını korumuşlardır. Bu dönemde bankacılık alanında gelen yabancı sermaye yatırımlarında Almanya'nın da rolü artmıştır (Akgüç, 2007, s. 9).

1883 yılında Osmanlı İmparatorluğu'nda bulunan yabancı sermayeli banka ve banka şubeleri İstanbul'da bulunan Osmanlı Bankası, Credit Lyonnais (İstanbul Şubesi), Bağdat'ta bulunan Londra 
ve Bağdat Derneği ve son olarak İstanbul'da bulunan Yeni Zelanda Ulusal Bankasıdır (Cottrell 2008: 71). $\mathrm{Bu}$ tarihten sonra yirmi y1l içinde, Osmanlı topraklarında bulunan yabancı bankaların şube sayısında bir değişiklik olmasa da daha sonrasında hızla artmaya başlamıştır.1899'da Hayfa, Yafa ve Kudüs'te Deusche Palastina Bankası üç adet şube açmıştır. Bu dönemde Alman bankaları da Osmanlı topraklarında yatırımlarını arttıran Alman şirketlerine yardımcı olmak için şube sayılarını arttırmaya başlamışlardır. Bu rekabette geri kalmak istemeyen Osmanlı Bankası ve Credit Lyonnais Bankası da yeni şubeler açmışlardır. 1913 yılına gelindiğinde Osmanlı topraklarındaki yabancı banka şubeleri ve yabancı sermaye ile kurulan bankalar Tablo 2'de gösterilmiştir.

Tablo 2. 1913 Yılında Osmanlı Topraklarında Yabancı Sermayeli Bankalar

\begin{tabular}{|l|l|}
\hline Bankanın İsmi & Bulunduğu Yer \\
\hline Bank-1 Osmani-i Şahane & $\begin{array}{l}\text { İstanbul (3 şube), Anadolu'nun çeşitli illerinde ve } \\
\text { Orta Doğuda (43 şube) }\end{array}$ \\
\hline İngiliz-Filistin Ortaklığı & Hayfa, Yafa \\
\hline Atina Bankası & Mersin, İstanbul, İzmir \\
\hline Şark Bankası & Magnésia, Mételiu, İzmir, Soma \\
\hline Selanik Bankası & $\begin{array}{l}\text { Edirne, Dedeağaç, Kırk-Kilise, Manastır, İzmir, } \\
\text { Souffi, İstanbul, Trablus }\end{array}$ \\
\hline Karadă̆ Bankası & Arnavutluk \\
\hline İngiliz Doğu Bankası & İzmir \\
\hline Crédit Lyonnais & İstanbul (3), Yafa, İzmir \\
\hline Deutsche Bank & İstanbul \\
\hline Deutsche Orient Bank & Adana, Bursa, İstanbul, Dedeağaç, Mersin \\
\hline Deutsche Palastina Bank & Şam, Hayfa, Yafa, Trablus \\
\hline Doğu Bankası Ortaklığ1 & Bağdat \\
\hline $\begin{array}{l}\text { Türkiye Ulusal Bankası (National Bank of } \\
\text { Turkey) }\end{array}$ & İstanbul \\
\hline Yabancı Ticaret için Rus Bankası & İstanbul \\
\hline Macaristan Bankası Ticaret & İstanbul, İzmir \\
\hline Wienner Bank- Verein & İstanbul, İzmir \\
\hline
\end{tabular}

Kaynak: A Survey of European Investment In Turkey, 1854-1914: Banks and the Finance of the State and Railway Construction, Contrell, 2008, s. 73

Osmanlı topraklarında yatırım yapan yabancı bankalar hem Osmanlı Devleti'ne borç sağlamış hem de demiryolu yapımlarında yararlı olmuşlardır. Bank-ı Osmani-i Şahane kurulması ile özellikle İngiltere ve Fransa'nın Osmanlı Devletine borç vermesi kolaylaşmışıı. Çünkü banka Fransa ve İngiltere adına Osmanlı maliyesi ve hazinesini denetimi altına almış ve tahvillerin bu ülkelerin borsalarında satılması için ön ayak olmuştur. Bu bankanın varlığı Avrupalı sermayedarlara, bankalara, bankerlere ve tasarruf sahiplerine büyük güvence vermiş ve 1863'den başlayarak Osmanlı İmparatorluğunun bir süre kolay borç bulmasını sağlamıştır (Sevimay, 1995, s. 290). Alman sermayesi ile kurulmuş olan Deutche Bank ise Osmanlı topraklarında yatırım yapan Alman sermayedarları desteklemiştir. Deutche Bank, demiryolları, petrol, deniz taşımacıllğı ve daha farklı dallarda iş yapan şirketlerde hisseye sahipti (Ortaylı, 2008, s. 73). Özellikle Bağdat demiryolları başta olmak üzere, demiryolları yapımında da Alman sermayedarlara destek vermiştir.

Bankacılık sektöründe, Osmanlı topraklarında toplam sermaye yatırımlarının 1895 yılında \% 31,2 ve 1914 yılında \% 21,7'siyle en çok yatırım yapan ülke Fransa olmuştur. Fransız sermayesi bu sektördeki yabancı yatırımların \% 75'inden fazlasını temsil etmekteydi. Bu durum Osmanlı Bankasında Fransız yatırımlarının öne çıkması ve İngiliz sermayesinin azalmasının bir sonucuydu (Thobie, 2008, s. 131).

\section{20. YÜZYILIN BAȘLARINDA OSMANLI TOPRAKLARINDA YABANCI BANKALAR ARASINDAKİ REKABET}

1900'lü yıllardan itibaren Avrupalı bankaların bu topraklarda aralarındaki rekabet artmıştır. Yeni yabancı bankalar açılmaya başlamış ve birçok banka da şube sayısını arttırmıştır. 1908'den itibaren 
toplamda 7 -8 yabancı banka on yedi şubeleriyle İstanbul'da faaliyet göstermeye başlamıştır. Bunun yanında altı yabancı banka İzmir'de beş tanesi de Selanik’te çalışmaya başlamıştır. 1912 yılına gelindiğinde İstanbul, İzmir, Selanik'te yeni banka ya da banka şubesi açacak yer kalmamıştı. Ancak bu tarihte Deutsche Palastina ve Selanik bankası Beyrut'ta yeni şubeler açmışlardır. Kudüs'te Osmanlı bankasının şube açtığı bilgisini alan Credit Lyonnais ve Deutsche Palastina bankaları, Osmanlı bankasının yarattığı rekabet karşısında daha önceden burada açtıkları şubelerle çalışan müşterileriyle daha uzun dönemli anlaşmalar yapmışlardır (Clay, 1994, s. 593).

19. yüzyılın son çeyreğinde Osmanlı İmparatorluğu'ndaki Fransız etkisi ekonomik eylemlerle özdeşleştikçe, bankacılar ve sanayiciler politika yapımında daha fazla söz sahibi olmuşlardır (Fulton, 1996, s. 140). Bu dönemde Fransız sermayesi bankacılık konusunda yoğun olarak yatırım yapmış, bu nedenle çeşitli Vilayetlerdeki Fransız konsolosları da, Alman bankaları başta olmak üzere Fransız yatırımcılarla rekabet halinde olan yabancı sermayeli bankaları dikkatle takip etmişlerdir

\subsection{FRANSIZ-ALMAN BANKALARI ARASINDAKİ REKABET}

Osmanlı topraklarında 1914 yılında bankacılık sektöründe yapılan doğrudan yatırımların \% 77,4'ü Fransa'ya, \% 20'si İngiltere'ye, \% 0,8'i Almanya'ya aitti (Thobie, 1977, s. 482). 1880'lerden itibaren Fransa ile Almanya demiryolları konusunda olduğu gibi bankacılık alanında da rekabete girişmişlerdir. Almanya'nın payı az olsa da bu açılan Alman bankaları Fransa'nın tepkisini çekiyor ve bu yatırımlar Fransa tarafından yakından takip edilmiştir.

Bu dönemde Fransız Ekonomi ve Finans Bakanlığı arşivlerine göre İstanbul ve farklı vilayetlerdeki Fransız konsolosluklarından Dışişleri Bakanlığına gönderilen raporlarda, Fransa'nın Osmanlı İmparatorluğunda özellikle Alman bankalarının açtıkları şubeleri ve bu bankaların faaliyetlerini yakından takip ettikleri anlaşılmaktadır. Bu yazışmalara göre özellikle 20. yüzyılın başında Alman bankalarının açtıkları şubelerin sayıları artmıştır. Dikkat çeken bir diğer durum da bu bankaların İstanbul dışında Suriye, Filistin gibi Fransızların çıkarlarının yoğun olduğu bölgelerde faaliyet göstermeleridir. Bu bölgelerde Alman bankalarının, Osmanlı Bankasına rakip olma ihtimalinin Fransız yetkililerini rahatsız ettiği görülmektedir.

İstanbul dışındaki vilayetlerde de Fransız yetkililerin Alman bankalarının faaliyetlerini izledikleri şu belgelerden anlaşılmaktadır. 9 Kasım 1909'da Halep'teki Fransız Konsolosu M. Laronce imzalı nota göre Halep'te Deutche Palestina Bankası şube açmıştır. Konsolosun bu banka hakkındaki yorumu yazdığı rapora şu şekilde yansımıştır:

“Halep’te bu bankaya kesinlikle yer vardır ve ne tür işler yapacağını kestirmek zordur. Bu şehirde Osmanlı Bankasının ve diğer özel bankaların varlı̆̆ı, bu bankanın karını düşürecektir. Yeni şube temkinli bir şekilde ilerleyecek gibi gözükmektedir." (Fransız Ekonomi ve Finans Bakanlığı arşivleri, dosya: B 0031284/1, no:32)

26 Nisan 1910'da gönderdiği raporda Konsolos M. Laronce, Dışişleri Bakanı Stephen Pichon'a Halep'te Deutche Bank tarafından kurulacak yeni şube hakkında bilgi vermiştir. 9 Kasım 1909'da gönderdiği yazıda Halep'te kurulan Deutche Palestina Bankasına ait şube hakkında, bu banka işlemlerinde temkinli hareket etmektedir yorumunda bulunmuştur ve şunları eklemiştir:

"Alman sermayedarlar bu bölgede daha ciddi işler peşindedir. Deutche Bank yeni bir şube açmıştır ve bu üzerinde durulmasl gereken bir durumdur. Banka şehrin merkezinde, 10 yılllğına büyük bir bina kiralamıştır. Sekiz, on kadar memur işe alınmış ve şube çalışmaya 1 Mayıs'ta başlayacaktır. Başlangıç için şubeye on beş bin mark gönderilmiş ve şube kurulana kadar bu para Osmanl Bankasina yatırlmıştır. Halep'de Deutche Bank Osmanlı Bankasına önemli bir rakip olacaktır. Bu bankanın müşteri çekmek için hiçbir fedakârlıktan çekinmeyecek, en iyi koşulları sunacak ve çok büyük riskler alacaktır. Banka kısa zamanda büyük bir iş potansiyeline ulaşıp yüksek kar oranına ulaşmayı hedeflemektedir. Osmanlı Bankası bu durumdan çok zarar görmese de küçük bankaların hızlı bir şekilde müşterilerini kaybedecekleri aşikârdır" (Fransız Ekonomi ve Finans Bakanlığı arşivleri, dosya: B 0031284/1,no:63). 
Bu yazışmadan bir ay sonra bu bankanın bu süreç içinde yaptığı çalışmalarla ilgili 30 Mayıs 1910'da Konsolos yeni bir rapor göndermiştir. Raporda Deutche Bank'ın çok iyi organize olduğunu ve bu kadar kısa sürede önemli işler başardığını anlatmıştır. Bankanın \% 7- 8 faizle verdiği borçlar 60000 lirayı geçmiştir.

"En başta Deutche Bank, buradaki Osmanlı Bankasıyla anlaşma yoluna gitmiş ancak bu anlaşmanın olabilmesi için Osmanlı Bankası bugüne kadarki tutumunu değiştirmesi gerekmektedir. Osmanlı Bankası bugüne kadar hiçbir zaman üç aydan uzun vadeli tahvilleri kırdırmamıştır. Deutche Bank ise 5 ve 6 ay vadeli kâğıtları kırdırmak için pazarlık yapmaktadır. Anlaşabilmeleri için, Osmanlı Bankası bugüne kadar ki uygulamasından vazgeçip bu yolu izlemesi gereklidir. Ayrıca Osmanlı Bankası kısa vadede kâğıtların iskonto oranlarını yükseltme eğilimindedir ve bundan da vazgeçmesi gerekmektedir Birkaç ay içinde iki banka arasında ciddi bir rekabet olacak ve yerli tüccarlar da bu durumdan yararlanacaklardır" (Fransız Ekonomi ve Finans Bakanlığı arşivleri, dosya: B 0031284/1,no:84) şeklinde raporunda belirtmiştir.

14 Eylül 1910'da Halep Konsolosu, Dışişleri Bakanına Deutche Orient Bank'1n bölgedeki ilerlemesini anlatan bir yazı göndermiştir. Bu yazıya göre "Deutche Orient Bank, Halep'e beş ay önce yerleşmesine rağmen Osmanlı Bankası'yla endişeye sebep olacak bir rekabet sürdürmektedir. Almanların burada uyguladıkları taktik, bu ülkedeki işleri ve insanları yakından tanımaktır. Burada yer edinmek için bu bölgede iyi tanınan kişileri işe almışlardır. Bu kişilerin çevrelerini ve özel ilişkilerini kullanarak pazarlıklar sırasında formalitelerden ve uzlaşmazlıktan uzak durmuşlar ve iş yapacakları kişilerin isteklerini ve alışkanlıklarını göz önünde tutmuşlardır. Ayrıca yaptıkları işlerde oldukça yumuşak bir tavır sergilemişlerdir. Ticari ihtiyaçlara uygun kararlar almışlar ve hiçbir idari zorluk çıkartmamışlardır."

Konsolos Halep'te Alman bankasının durumu hakkında şu yorumları yaparak devam etmiştir: "Şu an için Deutsche Orient Bank'ın yönetimi buradaki iş dünyasına çok sempatik davranıyor ve bu sayede gelecekte de önemli işler yapacak gibi gözüküyor. Maalesef aynı şeyi bu bankaya karşı müş̧erilerini kaybetmeye başlayan Osmanlı Bankası için söylemek mümkün değil. Bu bankanın yönetimi burada popüler değil ve yerel basında bu yönetime karşı çıkan haberler de bankaya zarar veriyor." Konsolos "Bu durum yönetimin suçu mu yoksa bankanın yönetmeliklerinin çok katı olmasının mı? Aynı zamanda bu bankanın eski gücüne ulaşması için ne yapmak gerekir" diye sormuştur (Fransız Ekonomi ve Finans Bakanlığı arşivleri, dosya: B 0031284/1, no:124). Bir başka belgeye göre Dışişleri Bakanı bu yazıyı Osmanlı Bankası yönetimi gerekli tedbirleri alsın diye Maliye Bakanına yollamıştır (Fransız Ekonomi ve Finans Bakanlı̆̆ arşivleri, dosya: B 0031284/1, no:1039).

Kudüs Konsolosu Gueyraud, 15 Eylül 1910'da bir başka Alman bankası olan Deutche Palestina Bankası hakkında Dışişleri Bakanı Stephen Pichon'a gönderdiği yazıda bu bankanın sermayesini beş milyondan yirmi milyona çıkardığını anlatmıştır. Konsolosa göre bu bölgedeki düşük ticari aktiviteler sebebiyle bu artışı açıklamak mümkün değildir. Gerçi bu banka Kudüs’teki kamunun yürüttüğü çalışmalara yoğun krediler vermektedir diye bu durumun sebebini açıklamıştır (Fransız Ekonomi ve Finans Bakanlığı arşivleri, dosya: B 0031284/1, no:34).

$\mathrm{Bu}$ bölgelerdeki konsoloslar sadece Alman bankalarının faaliyetlerini izlememişler aynı zamanda bunlara karşı Fransız bankalarının nasıl bir yol izlemesi gerektiğine dair de raporlar göndermişlerdir. 4 Şubat 1913'de Hayfa'daki Fransız İkinci Konsolosunun Dışişleri Bakanına Nablus'da kurulan Deutsch Palestina Bankası ile ilgili verdiği bilgide, bu bankanın faiz karşılığında çok miktarda mevduat topladığını anlatmıştır. İkinci Konsolos "Osmanlı Bankası, Deutsch Palestina Bankasının buradaki varlığını küçümsemektedir. Bu ülkede, halkın ihtiyaçlarını karşılayacak bir Fransız bankasının ortaya çıkması (ipotekle borç vermesi, mevduat hesabı açması, ticari kredi vermesi vs.) Almanların hızla ayağını kaydıracaktır. Belki Crédit Lyonnais ya da Comptoir d'Escompte buraya müfettişlerini gönderir ve buradaki iş olanaklarını araştırır" diye bu Vilayetteki durumu anlatımıştır.

28 Nisan 1913'de Hayfa'daki Fransız İkinci Konsolosunun Dışişleri Bakanına bölgedeki Alman yatırımları ve bunları ortadan kaldırma konulu mektubunda "Bu bölgeler bizim için olduğu kadar rakiplerimiz açısından da karlıdır" diye yazmıştır. "Buradaki yatırımlarımız bölge üzerindeki etkimizi 
arttırmaktadır. Suriye bölgesinde Lübnan'da ticaret yaptığımız Hıristiyan nüfus vardır. Bunların sermayeye ihtiyaçları vardır ve bunun için yeni yatırımcılar aramaktadırlar. Bu süreçte köylülerin büyük baskısı altındadırlar ve birçoğu topraklarını Siyonistlere satmaktadırlar. Bizim sermayedarlarımız burada varlık gösterseler bunun sonucunda oldukça karlı işler yapabilirler. Maalesef sermayedarlarımız bu toprakların çok riskli olduğunu ve İmparatorluğun çok ciddi sorunları olduğunu düşünüyorlar. Suriye bölgesinde sadece Crédit Foncier büyük bir firma açacak" şeklinde bölgedeki durumu bildirmiştir.

"Mali konulardaysa, bu bölgede Almanlar Deutch Palestina Bankası ile faaliyet gösteriyor. Bu bölgedeki halk için yaptıkları hiçbir şey göz ardı edilemez. Şubelerini mümkün olan her yerde açıyorlar. Biz de isteriz ki Crédit Lyonnais gibi bir Fransız bankası da bu bölgedeki işlemleri küçük görmesin ve Güney Suriye'ye yerleşsin. Bu banka müfettişlerini bölgeye gönderip bu durumu incelemelidir. Burada çalışacak personelin kesinlikle Fransız hatta iyi Fransız olmasına dikkat etmeleri gerekmektedir. Bu bölgedeki Fransız sermayedarların eksikliği buradaki çıkarlarımıza yıllardır zarar vermektedir. Bu boşluğu Almanlar doldurmaktadır. Suriye ve Mısır bölgesinde Almanlar tarafından yönlendirilen İtalyanlar, Yunanlılar, İngilizler bize karşı çalışmaktadır” diye eklemiştir.

Bu yazışmalardan özellikle Suriye, Filistin bölgesinde Alman bankaları ile Osmanlı Bankası arasında bir rekabet olduğu anlaşılmaktadır. Alman bankalarının Osmanlı Bankasına karşı ciddi bir rakip olduğu da Konsolosların gönderdiği raporlardan anlaşılmaktadır. Fransızlar bu bölgelerdeki etkilerini kaybetmek istemedikleri için Alman bankalarının kendilerine karşı rakip olma ihtimalinden rahatsız olmuşlardır.

Sadece Suriye, Filistin bölgesinde değil, Balkanlarda da Alman bankaları faaliyetlerini arttırmışlardır. 14 Nisan 1910'da Edirne'deki Fransız Konsolos yardımcısı M. Tinayre, Dışişleri Bakanına yazdığı mektupta Edirne'de açılacak yeni bankaları anlatmıştır. Bu mektuba göre Deutche Orient Bankası ve Selanik Bankası Edirne'de şube açmak istemişlerdir. Bu tarihe kadar buradaki tek finans kuruluşu Osmanlı Bankası ve birkaç küçük bankadır. Konsolos yardımcısına göre son zamanlarda bu vilayetteki askerlerin sayısının artması buradaki iş ortamına bir canlılık getirmiştir. Bu nedenle banka sayısı artmıştır. M. Tinayre'nin aldığı bilgiye göre Deutche Orient Bankası burada Alman sermayesini kullanarak sanayi kuruluşları kurmayı düşünürken, Selanik Bankası ticari işler yapacaktır. " $\mathrm{Bu}$ bankaların yaratacağı rekabet sonucunda borç vermek eskisine oranla zorlaşacak ve bankalar daha riskli işler yapacaklardır. Bu durumda Edirne'de iflaslar artacaktır" diye bu şehirde yeni açılacak banka şubelerinin yaratabileceği sorunlar hakkında yorumda bulunmuştur.

Balkanlarda, Fransız yetkililerinin yazışmalarına yansıyan bir diğer hareket de 1911 yılında Deutche Orient Bank'ın İskeçe'de açtığı şubedir. Konuyla ilgili Selanik'teki Fransız Konsolosu M. Jousselin, 23 Haziran 1911'de Dışişleri Bakanı M. Cruppi'ye bir yazı göndermiştir. Bu dönemde İskeçe'de Osmanlı Bankası, Selanik Bankası ve Atina Bankası vardır. Bu Vilayette yeni şubelerin açılmasındaki en önemli sebep tütün üretiminin artmasıdır. Bu bölgede yoğun olarak buğday da üretilmekte ve nüfusun gıda ihtiyacını karşılamaktadır.

\subsection{OSMANLI TOPRAKLARINDA FAALIYET GÖSTEREN ALMAN BANKALARININ KENDİ ARALARINDAKI REKABET}

Fransız yetkililere göre Alman bankaları arasında da rekabet vardı. 20 Temmuz 1909'da Fransız Maslahatgüzarı M. Boppe'dan Dışişleri Bakanına, İstanbul'daki Alman bankalarına ilişsin gönderdiği bilgilendirme notunda şu bilgileri vermiştir:

"Deutche Bank doğudaki menfaatlerini korumak için Anadolu Şirketi'nin (Compagnie d'Anatolie) tüm işlerinde ortak çalışmaktadır. Deutche Bank İstanbul'da bir şube açmaya karar vermiş ve bu şubede çalışacak personel de büyük bir dikkatle seçilmiştir. Genel müdürlüğe daha önce İspanya'da çalışmış olan M. Hoffmann getirilmiştir. Aynı zamanda Osmanlı Bankasının seçkin memurları da bu banka tarafından işe alınmıştır. Deutche Bank, İstanbul'da rakip bir Alman bankası nedeniyle şube açmak zorunda kalmıştır. Bu banka son yıllarda büyük bir gelişme gösteren Deutche Orient Bank'tır. $\mathrm{Bu}$ banka diğer finans kuruluşlarına göre daha cesaretli işlere ön ayak olmaktadır. Daha az kar elde ederek geleceği parlak işlere girmekte ve Türklerle yakın ilişkiler kurmaktadır. Bankanın başarısı 
Deutche Bank'1 endişelendirmektedir. Bu rekabet Deutche Bank'ın İstanbul'da bir şube açmasını zorunlu kılmıştır." Bu notta açık olarak Alman bankalarının sadece diğer ülkelerin bu bölgedeki bankalarıyla değil kendi aralarında da rekabet halinde oldukları anlaşılmaktadır.

Deutche Bank'ın İstanbul'daki yöneticisi Kauffmann, Filistin ve Suriye bölgelerine Deutche Palastina Bankası'nın faaliyetlerini incelemek için ziyarette bulunmuştur. Bu ziyaretle ilgili 30 Kasım 1910'da Kudüs'teki Fransız Konsolosu Dışişleri Bakanına gönderdiği bir yazıda "Deutche Palestina Bankası işlerini daha itibarlı şekilde yürütmek için sermayesini 5 milyon marktan 25 milyon marka yükseltmiştir demiştir. Ancak bu rakam hala Credit Lyonnais ve Osmanlı Bankasının sermayelerinden azdır. Ancak Deutche Bank söz konusu olunca bu bölgede Fransız bankalarına tartışılmaz şekilde rakiptir" bilgisini vermiştir (Fransız Ekonomi ve Finans Bakanlığı arşivleri, dosya: B 0031284/1, no:47).

5 Aralık 1910'da İstanbul maslahatgüzarı M. Boppe, Dışişleri Bakanına Deutche Palestina Bankası ile ilgili bilgilendirme notu göndermiştir. $\mathrm{Bu}$ notta Alman bankalarının Osmanlı topraklarındaki faaliyetleri irdelenmiştir. Son dönemlerde Alman bankaları özellikle Suriye ve Filistin bölgelerinde yoğun faaliyet içindedirler. Bu bankaların bu bölgede yaptıkları işler Alman otoritelerini olduğu kadar sermayedarlar ve sanayicilerin de ilgisini çekmektedir. Son yıllarda Deutche Orient ve Deutche Palestina Bankalarının Suriye'de açtıkları şubelerin sayısı ikiye katlanmıştır.

Deutche Palestina Bankası Hamburg'da da bir şube açarak Alman denizcilik şirketleriyle özellikle de Deutche Levant Linie ile ilişkilerini güçlendirmiştir. Aynı zamanda maden kömürü işletmeciliği, sigortacılık ve taşımacılık alanında iş yapan birçok Alman şirketi ile ortaklık kurmuştur. 1907 yılında Beyrut'ta, 1909'da Halep'te, 1910'da Suriye bölgesinde, Trablus ve Adana'da şube açmıştır. Maslahatgüzara notta "Görünen odur ki bu bölgelerde sanayicilere ve belediyelere verilen krediler için Deutche Orient Bankası, Deutche Bank ile rekabete girecektir. M. Kauffmann buraya yaptı̆̆ ziyarette bunu görmüş olmalıdır" (Fransız Ekonomi ve Finans Bakanlığı arşivleri, dosya: B 0031284/1, no:507) diye eklemiştir. Bu yazışmalardan, Alman bankalarının Fransızların çıkarlarının yoğun olduğu Suriye, Filistin bölgesindeki faaliyetlerinin artmasının Fransız yetkililerini kaygılandırdığı anlaşılmaktadır.

\subsection{INGILIZ SERMAYELİ TÜRKIYYE MILLI BANKASI (NATIONAL BANK OF TURKEY)}

Almanların yanı sıra İngiliz sermayedarların banka açma projeleri de Fransız yetkililerinin yazışmalarının konusu olmuştur. Daha önce İngiliz sermayesi ile 1856 yılında Osmanlı Bankası kurulmuş ancak 1863 yılında bu bankaya Fransız sermayedarlar ortak olmuştur. Bu bankada ağırlık Fransızların eline geçince Osmanlı topraklarında İngilizleri temsil edecek güçlü bir finans kurumu kalmamıştır. İngiliz finansçılar yeterince güvenilir bulmadıkları bu topraklarda yatırım yapmaya başta çok istekli olmasalar da, 1908 yılındaki İkinci Meşrutiyetin ilanından sonra İngiliz yatırımcıların bu topraklara ilgisi artmıştır. İngiltere'nin Duyun-u Umumiye'deki temsilcisi Adam Block ve İngiltere'nin önemli maliyecilerinden biri olan Ernest Cassel, Osmanlı topraklarında bir İngiliz bankası kurulmasından bahsetmişlerdi (Karabulut, 2018, s. 381-382).

15 Şubat 1909'da Fransız Dışişleri Bakanından Maliye Bakanına giden çok gizli ibareli yazıda İngilizlerin, Osmanlı topraklarındaki mali projeleri anlatılmıştır. Bu belgeye göre Londra'daki Fransız Büyükelçisi, Sir Adam Block ve Sir Ernest Cassel ile arkadaşlarının Osmanlıda yeni bir banka açma projeleri olduğunu bildirmiş̧ir. $\mathrm{Bu}$ banka Fransız çıkarlarına ters düşmektedir çünkü Osmanlı Bankasına rakip olma ihtimali yüksektir. Aynı zamanda Alman finans kurumlarıyla yakın ilişkileri vardır ve Almanlar bu bankayı İstanbul'da faaliyetlerini yoğunlaştırmak için kullanabilirler. Dışişleri Bakanına göre bu bankayı açma düşüncesi henüz olgunlaşmamıştır ancak yine de Fransızların doğudaki çıkarları ters düştüğü için büyük bir dikkatle izlenmelidir (Fransız Ekonomi ve Finans Bakanlığı arşivleri, dosya: B 003184/2, no:153).

Bu banka Türkiye Milli Bankası adıyla 1909 yılında İstanbul'da kurulmuştur. Bankanın ana sermayesi 3300000 liradır ve 300000 hisseye bölünmüştür. Hisselerin 30000 tanesi Osmanlı tebaasından kişilere satılması planlanmıştır. Bankanın amacı Osmanlı Devleti'nin ekonomik gelişmesini 
sağlamaktır. Bu nedenle banka yetkilileri sanayi ve ticaret kuruluşları, altyapı projeleri, ormancılık ve maden işleri için krediler vermeyi düşünmektedir (Fransız Ekonomi ve Finans Bakanlığ arşivleri, dosya: B 00331284/2²). Bu bankanın sermayesi Bank-1 Osman-i Şahane'nin sermayesinin üçte biri kadardır (Conlin, 2016, s. 525). Ancak yine de rakip olabilme ihtimali Fransız yetkilileri rahatsız etmiştir. Fransızlara göre İngilizlerin, Osmanlı Bankasına rakip olabilecek bir bankanın kuruluşuna destek vermeleri iyi bir fikir değildir. Bunun yerine Osmanlı Bankasında İngiliz etkisi yeniden arttırılabilir.

\section{SONUÇ}

Osmanlı İmparatorluğunun mali sorunları 17. yüzyıldan itibaren artmıştır. Yenilgiyle sonuçlanan uzun savaşlar devletin harcamalarını arttırmıştır. Devletin gelirleri ise vergilerin hazineye ulaşamaması sonucunda yetersiz kalmıştır. 19. yüzyılda merkezi devlet vergi gelirlerini artırmak için önlemler alsa da bu bile mali sorunları azaltamamıştır. Devlet sürekli tağşiş yapmak zorunda kaldığı için para düzeni de bozulmuştur. Para düzeninin bozulması sonucunda yabanc1 tüccarlar ve onlara destek veren batılı devletler banka kurulması konusunda baskılarını arttırmışlardır. 1856 yılında ilan edilen Islahat Fermanında ilk defa bir banka kurulmasından bahsedilmiştir. 1847 yılında iki Galata bankeri tarafından kurulmuş Dersaadet Bankası'nın ömrü çok uzun olmasa da yeni bir banka kurmak için yerli ve yabancı sermayedarlardan birçok teklif gelmiş ve 1856 yılında İngiliz sermayedarları Osmanlı Bankası'nı kurmuştur. 1863 yılında Fransız sermayedarlar da bu bankaya ortak olmuşlardır.

Yabancı bankalar, mali sorunları sebebiyle Kırım Savaşı sırasında dış borç almaya başlayan Osmanlı Devletine borç bulmak konusunda yardımcı olmuşlardır. Aynı zamanda yabancı bankalar kendi yatırımcılarını da desteklemişlerdir. Özellikle yabancı sermayedarların yaptıkları demiryollarını para desteği sağlamışlardır. Bu noktada özellikle bir Alman bankası olan Deutsche Bank'ın kendi yatırımcılarına sağladığı finansal destekten bahsedilebilir.

Fransa, Osmanlı İmparatorluğu yıkılana kadar kurulan yabancı bankaları yakından takip etmiştir. Fransız Ekonomi ve Finans Bakanlığı arşivlerine göre Fransız konsoloslar farklı Vilayetlerde özellikle Osmanlı Bankası'na rakip olarak gördükleri Alman bankalarının ne gibi işlemler yaptıkları hakkında birçok rapor yazıp göndermişlerdir. Özellikle Halep, Şam gibi Fransız etkisinin yoğun olduğu yerlerde Alman bankalarını daha da yakından takip ettikleri anlaşılmaktadır.

Bunun yanında Fransızlar, Alman bankaları arasındaki rekabete de dikkat etmiştir. Ayrıca Alman bankaları dışında Osmanlı Bankası'ndaki etkisi azaldığı için 1909 yılında yeni bir banka kuran İngilizlerinde bu bankayla Osmanlı Bankası'na rakip olacaklarını düşünmüşlerdir. Bu bankayı kurmak yerine Osmanlı Bankası'ndaki etkilerini arttırmanın daha iyi bir fikir olduğundan bahsetmişlerdir.

$\mathrm{Bu}$ çalışmada, Fransız sermayedarların, Osmanlı İmparatorluğunda kurulan yabancı sermayeli bankalarda önemli bir paya sahip oldukları ve Osmanlı Bankası sebebiyle Fransızların kendilerine rakip olabileceğini düşündükleri yabancı bankaları ve yabancı banka şubelerini yakından takip ettikleri anlaşılmaktadır. Net olarak görülmektedir ki sanayileşmiş devletler arasında diğer yatırım alanlarında olduğu gibi bankacılık alanında da Osmanlı topraklarında rekabet vardır. Fransızlar bu rekabette etkilerini kaybetmek istememişlerdir ve İngiltere, Almanya gibi özellikle Bank-1 Osman-1 Şahane’ye rakip olabilecek yabancı sermayeli bankaları yakından takip etmiştir.

\section{Bilgilendirme / Acknowledgement:}

1- Makalemizde etik kurulu izni ve/veya yasal/özel izin alınmasını gerektiren bir durum yoktur.

2- Bu makalede araştırma ve yayın etiğine uyulmuştur.

2 Bu yazı, Türkiye Milli Bankası ile ilgili bilgilendirme notudur. Ancak hangi tarihte, kime gönderildiği belgede yer almamaktadır.

IBAD Sosyal Bilimler Dergisi / IBAD Journal of Social Sciences, (8), Güz/Fall 2020 


\section{KAYNAKÇA}

Akgüç, Ö. (2007). Türkiye'de yabancı bankalar. Muhasebe ve Finansman Dergisi, 36, 6-17.

Apak, S. ve Tay, A. (2012). Osmanlı devletinin 19. yüzyıldaki finansal sisteminde Osmanlı Bankasının yeri ve faaliyetleri. Muhasebe ve Finans Tarihi Araştırmaları Dergisi, 3, 63-103

Ayoglu Duman, D. (2016). La concurrance entre les banques Françaises et Allemandes. Archivum Ottomanicum, 33, 47-55

Aysan, M. A. (2018). Dünyada ve Osmanlı devletinde enflasyon. Accounting and Financial History Research Journal, 92-123

Conlin, J. (2016). Debt, diplomacy and dreadnoughts: The National Bank of Turkey, 1909-1919. Middle Eastern Studies, 52(3), 525-545

Contrell, P. L.(2008). A survey of European investment in Turkey, 1854-1914: banks and the finance of the state and railway construction. East meets west - banking, commerce and investment in the Ottoman empire içinde. 59-95. London: Ashgate Publishing Company.

Clay, C. (1994). The origins of modern banking in the Levant: the branch network of the Imperial Ottoman Bank, 1890-1914. Middle east studies, 26(4), 589-614

Frangakis-Syrett, E. (2009). Banking in İzmir in the early twentieth century. Mediterrean historical review, 24(2), 115-132

Fransız Ekonomi ve Finans Bakanlı̆̆ Arşivleri. no:307, B 0031284/1, no:32, B 0031284/1,no:63, B 0031284/1, no:84, B 0031284/1, no:124, B 0031284/1, no:1039, В 0031284/1, no:34, B 0031284/1, no:47 B 0031284/1, no:507, B 003184/2, no:153.

Fulton, B.L., K (Ed.) (1996). France and the end of the Ottoman empire. The great powers and the end of the Ottoman Empire içinde. 2. Basım. 137-165. London: Deakin university. Taylor and Francis e-library.

Güran, T. (2014). 19. yüzyılda Osmanlı ekonomisi üzerine araştırmalar. İstanbul: Türkiye İş Bankası Kültür Yayınları

Hanedar, A. Ö. (2015). Foreign bank entry in the late Ottoman empire: the case of the Imperial Ottoman Bank. Review of Middle East Economics and Finance, 11(3), 207-223

İstanbul Menkul Kıymetler Borsası (1999). Osmanlı'dan günümüze Türk finans tarihi.1. İstanbul: Creative Yayıncılık ve Tanıtım Ltd. Şti.

Karabulut, I. (2018). Osmanlı'dan Cumhuriyet'e Türkiye'de yabancı bankaların çalışmaları: Türkiye Milli Bankası örneği. Akademik Sosyal Araştırmalar Dergisi, 85(6 ), 379-406

Karta, N. (2014). 18. ve 19. asırda Avrupa'da para, banka ve mevduat alanında yaşanan gelişmelerin Osmanlı İmparatorluğu yansımaları. Atatürk Üniversitesi İktisadi ve İdari Bilimler Dergisi, 28(1), 149- 164

Kazgan, H. (1997). Osmanlı'dan Cumhuriyet'e Türk bankacılık tarihi. İstanbul: Creative Yayınc1lık ve Tanıtım Ltd. Şti

Ortaylı, İ. (2008). Osmanlı İmparatorluğu'nda Alman nüfusu. 10. basım. İstanbul: Timaş Yayınları

Pamuk, Ş. (2014). Türkiye'nin 200 yıllık iktisat tarihi. 1.basım. İstanbul: Türkiye İş Bankası Kültür Yayinlar1

Pamuk, Ş. (2017). Osmanlı'dan Cumhuriyet'e küreselleşme, iktisat politikalarl ve büyüme. 4. basım. İstanbul: Türkiye İş Bankası Kültür Yayınları

Sevimay, R.S. (1995). Cumhuriyet'e girerken ekonomi Osmanl son dönem ekonomisi. İstanbul: Kazancı Kitap Tic. A.Ş. 
Tabakoğlu, A. (2009). Türkiye iktisat tarihi. 9. Basım. İstanbul: Dergâh Yayınları

Türkiye Bankalar Birliği (2008). 50. Yılında Türkiye Bankalar Birliği (TBB) ve Türkiye’de bankacllı sistemi 1958-2007. İstanbul: TBB Yayınları

Thobie, J. (1977). Interets et imperialisme français dans l'empire Ottoman (1895-1914). Paris: Publication de la Sorbonne

Thobie, J, C. (Ed.) (2008). French investment in public and private funds in Ottoman empire on the eve of the great war. East meets west, banking, commerce and investment in the Ottoman empire içinde. 123-143. London: Ashgate Publishing Company 